\title{
Implementing Tolerance Values and Patriotsm Through History Learning at SMA Negeri 11 Yogyakarta
}

\author{
Muslim, Warto, Djono
}

Universitas Sebelas Maret, Surakarta

muslim_161194@yahoo.com

\author{
Article History \\ accepted 1/09/2020
}

approved 4/10/2020 published 1/12/2020

\begin{abstract}
This study aims to obtain: (1) inculcating the values of tolerance and patriotism through learning history, (2) difficulties experienced by history teachers, and (3) efforts made by history teachers to overcome these difficulties. This study uses qualitative methods, with a single embedded case study strategy. This study was conducted at SMA Negeri 11 Yogyakarta. Data were collected through observation, in-depth interviews, and document study. The data analysis technique used the interactive model of Miles and Huberman's analysis. The results of the study show that: (1) Cultivating the values of tolerance and patriotism, namely through learning preparation, learning implementation, (using the discussion method, because in discussions it is easy to instill the values of tolerance and patriotism in students), and evaluation. (2) The difficulty faced by history teachers is that they have little time to study, and nowadays online learning makes it difficult for teachers to socialize with students. (3) Efforts made by history teachers, in overcoming these difficulties, were to make themselves role models and motivators for their students. In the end, after the obstacles are overcome, the values of tolerance and patriotism increase.
\end{abstract}

Keywords: Tolerance, patriotism, values, history learning

\begin{abstract}
Kajian ini bertujuan untuk memperoleh: (1) Penanaman nilai-nilai toleransi dan patriotisme melalui pembelajaran sejarah, (2) Kesulitan yang dialami oleh guru sejarah, dan (3) Upaya yang dilakukan guru sejarah untuk mengatasi kesulitan tersebut. Kajian ini mengunakan metode kualitatif, dengan strategi studi kasus terpancang tunggal. Kajian ini dilaksanakan di SMA Negeri 11 Yogyakarta. Data dikumpulkan melalui observasi, wawancara mendalam, dan studi dokumen. Teknik analisis data mengunakan model analisis interaktif Miles dan Huberman. Hasil kajian menunjukkan bahwa : (1) Penanaman nilai-nilai toleransi dan patriotisme, yakni melalui persiapan pembelajaran, pelaksanaan pembelajaran, (mengunakan metode diskusi, karena dalam diskusi mudah untuk menanamkan nilai-nilai toleransi dan patriotisme pada diri siswa), dan evaluasi. (2) Kesulitan yang dihadapi guru sejarah adalah waktu belajar yang sedikit, dan sekarang ini pembelajaran daring (online) maka guru sulit untuk bersosialisasi dengan siswa. (3) Upaya yang dilakukan guru sejarah, dalam mengatasi kesulitan tersebut adalah menjadikan dirinya sebagai teladan dan motivator bagi siswanya. Pada akhirnya, setelah hambatan diatasi maka nilai-nilai toleransi dan patriotisme meningkat.

Kata Kunci: Toleransi, patriotisme, nilai, pembejaran sejarah
\end{abstract}

Social, Humanities, and Education Studies (SHEs): Conference Series https://jurnal.uns.ac.id/shes

p-ISSN 2620-9284 e-ISSN 2620-9292 
SHEs: Conference Series 3 (2) (2020) 60 - 68

\section{PENDAHULUAN}

Sejak awal abad ke-20 Republik Indonesia sebagai sebuah Bangsa sesungguhnya sudah merintiskan diri sebagai sebuah negara. Kebangkitan nasional menjadi salah satu titik penting sebagai langkah awal mencapai kemerdekaan. Berikutnya, Sumpah Pemuda adalah momen penting yang menyatukan beragam perbedaan. Hingga akhirnya, 17 Agustus 1945 menjadi titik puncak perjuangan Bangsa Indonesia, yaitu kemerdekaan Bangsa Indonesia. Terhitung lebih dari 70 tahun Bangsa Indonesia menikmati kemerdekaan, tentunya kemerdekaan yang didapat tidak lepas dari perjuangan panjang para pahlawan. Semangat juang dan patriotisme mereka yang telah membakar dan menimbulkan hasrat untuk merdeka (Sugiman 2017).

Pencapaian tujuan nasional Bangsa Indonesia yang dituangkan dalam Pembukaan Undang-Undang Dasar 1945 merupakan tugas dan kewajiban seluruh warga negara Republik Indonesia. Tanggung jawab dan keikutsertaan warga negara dalam pencapaian tujuan nasional tersebut merupakan perwujudan nilai toleransi dan patriotisme dalam bentuk kesadaran berbangsa dan bernegara, kecintaan terhadap tanah air, keyakinan terhadap nilai-nilai Pancasila sebagai ideologi, falsafah dan dasar negara, kerelaan berkorban bagi bangsa dan negara, serta kemampuan awal bela negara. Bangsa Indonesia adalah negara yang sangat majemuk dan beranekaragam, baik itu kebudayaannya maupun masyarakatnya. Keanekaragaman itu tentu saja merupakan suatu pedoman dan faham yang cocok dengan karakter kemajemukan itu sendiri. Paham yang dirasakan cocok dengan kemajemukan ini adalah konsep kebangsaan yaitu toleransi dan patriotisme.

Toleransi ialah satu bentuk sikap saling menghormati sesama dan tidak memaksakan kehendak diri sendiri. Manusia yang menggangap dirinya lebih tinggi dari orang lain, baik, dan benar kecederungan ini dapat menanamkan sikap yang anti toleransi. Sikap primordial yang menganggap bahwa budayanya lebih baik dari budaya lainnya inilah yang menjadi penyebab timbulnya perselisihan (Bakry 2010). Sedangkan patriotisme diartikan sebagai semangat atau jiwa yang dimiliki oleh seseorang untuk berkorban atau rela berkorban demi nama suatu bangsa dan negara (Sugiman 2017). Globalisasi memiliki pengaruh yang sangat kuat dan memunculkan keberagaman baru. Globalisasi yang memunculkan keberagaman baru bagi bangsa Indonesia, akan mempengaruhi nilai toleransi dan patriotisme bangsa Indonesia. Pengaruh negatif globalisasi terhadap nilai-nilai toleransi salah satunya ialah masyarakat Indonesia khususnya kaum muda banyak yang menganggap bahwa nilai-nilai yang terdapat dalam nilai toleransi dan patriotisme sudah tidak zaman lagi untuk dibicarakan dan dilaksanakan (Sugiman 2017).

Globalisasi sangat mengancam pemuda karena kondisi psikis pemuda terbilang masih labil sehingga mudah terpengaruh dari luar. Pemuda zaman sekarang sangat mudah terkena dampak westernisasi sehingga dengan sekejap bisa merubah nilai-nilai yang dipegang selama ini. Tetapi pemuda kurang sadar akan ancaman tersebut dan kurang menganggap pentingnya nilai-nilai toleransi dan patriotisme. Belakangan tawuran pelajar, pertikaian antar warga, pornografi, premanisme, prostitusi, pergaulan bebas ketika jauh dari pantauan orang tua, berpakaian seenak hati tanpa memikirkan adat istiadat dan parahnya tidak lagi menghormati orang tua (Fimansyah and Kumalasari 2015).

Tidak hanya itu korupsi bukan hanya menjadi bagian dari budaya, tetapi telah menjadi bagian dari mata pencaharian untuk mendapatkan tambahan bagi biaya hidup dan gaya hidup yang semakin melambung tinggi, bahkan sekarang ini dalam praktiknya justru semakin tersistematis dan terlihat telaten, yang disayangkan adalah nasib rakyat miskin yang semakin melarat sementara orang kaya akan semakin kaya dan menikmati berbagai macam fasilitasnya (Fimansyah and Kumalasari 2015). Senada dengan itu apabila melihat kondisi bangsa Indonesia hari ini, dimana krisis dalam berbagai sektor 
kehidupan masih banyak terjadi, kemiskinan, kriminalitas, kesenjangan sosial, pengangguran, pola hidup hedonis dan konsumtif, sikap individualis pergaulan masyarakat, korupsi, krisis identitas dan lunturnya nilai-nilai toleransi dan patriotisme, akademisi dan pelajar yang tidak bermoral dan masih banyak lagi, dalam dunia pendidikan terjadinya tawuran pelajar, seks bebas dikalangan pelajar, narkoba dikalangan pelajar, pola hidup hedonis dan konsumtif para pelajar. Gaya hidup pelajar sudah terpengaruh oleh budaya asing, pola hidup konsumtif dan bangga dengan produk luar negeri. Sikap apatis pelajar terhadap persoalan bangsa, lingkungan sekitar sudah menjadi hal yang biasa. Bahkan ada pelajar yang berani bersikap tidak hormat kepada guru. Kalau dibandingkan dengan cerita orang tua dulu, hampir tidak ada perilaku siswa yang berani melawan guru (Yefterson and Salam 2017).

Senada dengan itu, akhir-akhir ini Indonesia diusik dengan berbagai peristiwa seperti ISIS, Radikalisme, terosisme, HTI yang telah dibubarkan pemerintah kerena dikhawatirkan mengancam kebhinnekaan bangsa Indonesia berdasarkan pancasila. Pemahaman yang mendalam dan komitmen yang kuat serta konsisten terhadap prinsip dan semangat patriotisme dalam kehidupan bermasyarakat, berbangsa, dan bernegara yang berdasarkan pada Pancasila dan Undang-Undang Dasar 1945. Semangat kebangsaan perlu ditanamkan kepada seluruh komponen warga negara Indonesia, khususnya generasi muda sebagai generasi penerus. Cinta tanah air merupakan bagian dari patriotisme, toleransi semangat toleransi, dan patriotisme diperlukan untuk mencapai cita-cita nasional dan mengembangkan eksistensi kehidupan atas dasar nilainilai luhur bangsa (Wisnarni 2017).

Bisa dirasakan saat ini, nilai-nilai karakter bangsa, seperti, toleransi, patriotisme saling menghargai, kerjasama, sikap moral yang baik sudah mulai pudar dalam diri para pelajar bahkan cenderung hilang. Nilai-nilai di atas merupakan nilai yang lahir dari proses panjang perjalanan sejarah bangsa Indonesia. Nilai-nilai karakterini sebenarnya sangat penting dan masih relevan diinternalisasikan oleh siswa. Selama negeri ini masih memakai ideologi Pancasila, nilai karakter yang ada dalam Pancasila tersebut harus tetap diwariskan kepada generasi muda. Mata pelajaran di sekolah, salah satu mata pelajarannya adalah sejarah. Sesuai dengan tujuan pendidikan yang terdapat dalam UUD 1945 dan UU tentang SIKDIKNAS tahun 2003, pembelajaran sejarah memiliki peran yang sangat penting dalam rangka membentuk generasi muda yang berkarakter

dan berkepribadian sesuai identitas bangsa Indonesia (Yefterson and Salam 2017). Pengajaran sejarah seharusnya bukan hanya sebatas penyampaian fakta-fakta kering, tetapi harus menyampaikan nilai-nilai yang terkandung didalamnya sekaligus menanamkan nilai-nilai tersebut kepada siswa. Pengajaran sejarah yang berorientasi kepada penyampaian fakta saja tidak akan memberi pengaruh pada perubahan sikap dan kepribadian siswa. Sejatinya pengajaran sejarah melatih siswa untuk berpikir kritis dan berpikir historis, dalam arti mampu memahami nilai yang ada dalam setiap peristiwa sejarah serta menerapkannya dalam kehidupan sehari-hari (Yefterson and Salam 2017).

Mata pelajaran sejarah banyak sekali nilai-nilai karakter yang bisa dijadikan sebagai inspirasi dan pedoman bagi siswa untuk bersikap dan berperilaku dalam kehidupan sehari-hari. Hal ini disebabkan karena pada dasarnya nilai-nilai karakter yang

terkandung dalam mata pelajaran sejarah adalah nilai-nilai luhur bangsa yang telah mengakar dalam masyarakat Indonesia sejak zaman dahulu dan telah menjadi nilai

karakter bangsa Indonesia. Mata pelajaran sejarah merupakan gudangnya nilai-nilai karakter bangsa. Ini bisa dimaklumi karena sejarah mengajarkan tentang perjalanan bangsa dari dahulu sampai sekarang. Sejarah mampu mengajarkan banyak hal, misal kenapa ekonomi pada zaman masa lampau gagal, kenapa sistem politik zaman tertentu itu gagal, lalu siapa tokoh yang berhasil pada suatu zaman itu, kenapa tokoh itu bisa berhasil dan lain-lain. Nilai-nilai karakter dari tokoh sejarah seharusnya bisa menjadi pedoman bagi siswa dalam bersikap dan berperilaku. Siswa dituntut bisa belajar agar kesalahan pada zaman lampau tidak terulang kembali (Yefterson and Salam 2017). 
Pengajaran sejarah penting dalam pembentukan jiwa patriotisme dan rasa kebangsaan suatu pengetahuan sejarah yang ditunjang pengalaman praktis warga negara yang baik di sekolah membantu memperkuat loyalitas dan membantu anak-anak menemukan dirinya dengan latar belakang sejarah luas (Setianto 2019). Rowse, menegaskan bahwa sejarah adalah suatu mata pelajaran yang bernilai pendidikan tinggi. Senada dengan itu Collingwod, mengatakan bahwa nilai sejarah mengajarkan tentang manusia dan apa yang telah dilakukannya. Dalam konteks pembentukan identitas nasional, pengetahuan sejarah mempunyai fungsi fundamental (Setianto 2019). Pembelajaran sejarah berfungsi untuk menyadarkan peserta didik tentang adanya suatu proses perubahan dan perkembangan masyarakat dalam dimensi waktu dalam membangun pandangan serta kesadaran sejarah dalam menemukan, memahami dan menjelaskan jati diri bangsa di masa lalu, masa sekarang, dan masa yang akan datang di tengah perubahan dunia, selain itu sebagai acuan dalam rangka membangun sebuah persatuan bangsa dirasa perlu untuk memupuk nilai-nilai toleransi dan patriotisme, perjuangan bangsa Indonesia sejak dini Nilai-nilai patriotisme yang terdapat dalam pembelajaran sejarah ialah mencintai negara serta menghargai jasa-jasa para pejuang bangsa (Chaerulsyah 2014).

Mata pelajaran sejarah yang diajarkan di sekolah memiliki peran strategis dalam menanamkan nilai-nilai toleransi dan patriotisme pada diri siswa sehingga memiliki kesadaran terhadap eksistensi bangsanya. Karena tanpa bingkai moral, pengajaran sejarah yang terlalu mengedepankan aspek kognitif atau fakta-fakta keras saja tidak akan banyak pengaruhnya dalam rangka memantapkan apa yang sering disebut sebagai jati diri kepribadian bangsa. Guru, orang tua dan masyarakat setidaknya dapat menanamkan motivasi kepada siswa agar memiliki semangat belajar yang tinggi hingga akhirnya dapat menggunakan ilmu mereka kelak untuk mencerdaskan generasi selanjutnya dibarengi dengan menanamkan nilai-nilai kejujuran, toleransi, disiplin, dan mementingkan kepentingan bersama dari pada kepentingan pribadi, serta menghargai orang lain ini sudah merupakan indikator dari nilai-nilai toleransi dan patriotisme. Berdasarkan latar belakang di atas, penulis merasa penting untuk mengkaji mengenai penanaman nilai-nilai toleransi dan patriotisme melalui pembelajaran sejarah di SMA Negeri 11 Yogyakarta. Kajian ini dilakukan dalam pembelajaran sejarah pada mata pelajaran Sejarah Pergerakan Nasional di kelompok peminatan di SMA Negeri 11 Yogyakarta yang telah menerapkan kurikulum 2013.

\section{Teori}

\section{Landasan Teori}

Pembelajaran sejarah berperan dalam menanamkan nilai-nilai kearifan lokal yang terkandung pada masyarakat. Untuk menanamkan nilai-nilai kearifan lokal pada siswa yaitu perlu dikembangkan atau dimasukkannya materi pembelajaran sejarah yang ada di sekolah tersebut, misalnya memasukkan materi tentang ketokohan dan keteladanan seseorang yang berpengaruh di daerah setempat, yang dalam materi tersebut membahas riwayat hidup selama berjuang di daerah tersebut berupa pengaruh. Pembelajaran sejarah dalam hal ini mampu mengubah pandangan siswa lebih baikdan mampu meneladani apa yang ditinggalkan sehingga dapat membentuk karakter siswa (P. Firdaus dan Ahmad. 2018). Nilai ialah suatu yang berharga, baik menurut standar pemikiran (benar atau salah), estetika (baik atau buruk), etika (adil atau tidak adil), agama (dosa atau tidak), serta yang menjadi acuan terhadap sistem keyakinan diri maupun kehidupan manusia (Darmadi 2007). Santayana mengatakan bahwa nilai ialah suatu bentuk prinsip pandangan di dalam ilmu, tidak lebih kecil dari pada suatu kebenaran dalam hidup. Pandangan itu menganggap nilai itu suatu hal yang sangat penting dan perlu ada dalam kehidupan sebagai pedoman bertindak (Hazlitt 2003). Toleransi secara umum ialah suatu bentuk perilaku serta sikap manusia yang tidak menyimpang dari aturan, dimana seorang menghormati dan menghargai setiap kegiatan 
yang dilakukan oleh orang lain. Pengertian toleransi ini mengacu pada sikap terbuka, lapang dada, sukarela dan kelembutan. Singkat kata toleransi sama dengan sikap positif, dan menghargai orang lain dalam rangka menggunakan kebebasan asasi sebagai manusia (Casram. 2016) Patriotisme ialah suatu bentuk kecintaan dan ketaatan yang amat sangat pada bangsa dan negara, serta merupakan suatu unsur yang menguatkan perasaan, sikap, pandangan serta nilai-nilai pada negara.

\section{METODE}

Metodologi dalam kajian ini adalah metode kualitatif dimaksudkan untuk memperoleh gambaran yang lebih jelas tentang keadaan yang sedang berlangsung dan lebih menekankan pada proses dan makna. Kajian ini lebih menekankan pada proses penanaman nilai-nilai toleransi dan patriotisme melalui pembelajaran sejarah di SMA Negeri 11 Yogyakarta, sehingga menghasilkan kata-kata tentang persiapan pembelajaran, pelaksanan, evaluasi, dan kesulitan yang dihadapi, serta upaya guru sejarah dalam mengatasi kesulitan tersebut. Kajian ini mengunakan strategi kasus tunggal, karena kajian hanya dilakukan pada satu sasaran (satu lokasi, atau satu subjek). Data dikumpulkan melalui observasi, wawancara mendalam, dan studi dokumen. Teknik analisis data mengunakan model analisis interaktif Miles dan Huberman.

\section{HASIL DAN PEMBAHASAN \\ Penanaman Nlai-Nilai Toleransi dan Patriotisme Melalui Pembelajaran Sejarah Di SMA Negeri 11 Yogyakarta. \\ a. Persiapan Pembelajaran}

Persiapan pembelajaran pada dasarnya merupakan gambaran mengenai beberapa aktivitas dan tindakan yang dilakukan pada saat berlangsungnya proses pembelajaran (Hanum 2013) Majid mengungkapkan bahwa persiapan merupakan proses penyusunan materi pelajaran, penggunaan media pengajaran, penggunaan pendekatan dan metode pengajaran, dan penilaian dalam suatu alokasi waktu yang dilaksanakan pada masa tertentu untuk mencapai tujuan yang telah ditetapkan. Persiapan mencakup rangkaian kegiatan untuk menentukan tujuan umum (goal) dan tujuan khusus (objektivitas) suatu organisasi atau lembaga penyelengaaraan pendidikan, berdasarkan dukungan informasi yang lengkap (Fitri 2017) Menurut Leo Agung dan Sri Wahyuni ada beberapa manfaat yang dapat dipetik dari penyusunan persiapan pembelajaran, yakni: a) Melalui proses persiapan pembelajaran yang matang, akan terhindar keberhasilan yang bersifat untung-untungan. b) Persiapan pembelajaran sebagai alat untuk memecahkan masalah. c) Untuk memanfaatkan berbagai sumber secara tepat. d) Persiapan akan dapat membuat pembelajaran berlangsung secara sistematis (Agung, Leo \& Wahyuni 2013).

Tahap persiapan merupakan suatu proses yang dilaksanakan supaya tujuan yang di tentukan dapat tercapai. Menurut Emanuela Bintarti El tahap persiapan meliputi persiapan silabus sebagai pedoman dalam penyusunan Rencana Pelaksanaan Pembelajaran, Rencana Pelaksanaan Pembelajaran (selanjutnya disebut RPP) sebagai pedoman dalam mengajar dimana di dalamnya mencakup rancangan media, metode, materi, dan evaluasi pembelajaran (I Ilyasin, S Amin 2019) Tahap persiapan adalah tahap untuk melihat bagaimana kesiapan guru yang mengajarkan mata pelajaran sejarah untuk menyusun skenario pembelajaran, menyusun materi, melaksanakan pembelajaran, dan melakukan penilaian. Guru sejarah di SMA Negeri 11 Yogyakarta sudah menyiapkan persiapan pembelajaran dengan baik dengan satu RPP untuk 2 kali pertemuan, guru sudah menanamkan nilai-nilai toleransi dan patriotisme yang sudah dimasukan dalam RPP pembelajaran. Pada saat persiapan ini guru sejarah melakukan penyusunan program RPP selama satu semester pegembangan RPP dengan menanamkan nilai-nilai toleransi dan patriotisme contohnya nilai moralitas yang berupa 
sopan santun, nilai komunikatif, nilai semangat, menghargai temannya dan guru, tanggung jawab dengan menyelesaikan tugas-tugas yang diberikan guru, jujur, menerima perbedaan pendapat dalam diskusi kelompok dengan temannya yang lain.

\section{b. Pelaksanaan Pembelajaran}

Pendidikan sebagai usaha menyiapkan siswa menghadapi lingkungan yang mengalami perubahan yang semakin pesat. Perubahan masyarakat mencakup nilai yang disepakati oleh masyarakat tersebut. Sedangkan seluruh nilai yang telah disepakati oleh masyarakat disebut kebudayaan. Dalam hal ini, kebudayaan dikatakan sebagai suatu konsep yang memiliki kompleksitas tinggi (Zais 1976) Sedangkan (Dimyati \& Mudjiono 2013) mengatakan bahwa ilmu pengetahuan dan teknologi adalah nilai yang bersumber pada pikiran atau logika, sedangkan seni bersumber pada perasaan atau estetika. Dengan demikian nilai-nilai sosial budaya masyarakat bersumber pada hasil karya manusia, sehingga dalam menerima, menyebarluaskan, melestarikan, atau melepaskannya manusia selalu mengunakan akal. Pelaksanaan pembelajaran sejarah di SMA Negeri 11 Yogyakarta sudah direncanakan dalam perangkat pembelajaran.

Hal ini sesuai dengan yang dikemukakan oleh Nana Sudjana (2010) bahwa pelaksanaan pembelajaran adalah proses yang diatur sedemikian rupa menurut langkah-langkah tertentu agar pelaksanaan mencapai hal yang diharapkan. Pelaksanaan pembelajaran sejarah yang terinternalisasi dengan nilai-nilai toleransi dan patriotisme terdiri dari tiga tahapan kegiatan, yaitu kegiatan pendahuluan, kegiatan inti, dan kegiatan penutup.

Pembelajaran sejarah dilaksanakan melalui media sosial WhatsApp, Google School, dan Google Clasroom. Pembelajaran sejarah yang diajarkan adalah materi sejarah pergerakan nasional, materi ini merupakan sarana yang tepat dalam menanamkan nilai-nilai toleransi dan patriotisme pada diri siswa di SMA Negeri 11 Yogyakarta, karena SMA Negeri 11 Yogyakarta ini merupakan sekolah yang dulunya pernah menjadi tempat dilaksanakannya kongres pertama Budi Utomo pada tahun 1908, yang merupakan simbol dari kebangkitan nasional. Proses pembelajarannya mengunakan metode diskusi, karena dalam diskusi mudah untuk menanamkan nilai-nilai toleransi dan patriotisme kepada siswa, contohnya siswa dilatih untuk percaya diri berbicara didepan orang banyak, siswa dilatih bagaimana menghargai pendapat temannya yang lain, siswa berlatih bagaimana berkomunikasi yang baik dengan cara menyampaikan pendapatnya dan menanggapi pendapat orang lain, tetapi karena sekarang ini pembelajarannya daring (online), maka guru memerintahkan siswa membuat makalah individu dan mind mapping berkelompok, kemudian tugas ini nantinya diupload di Google Classroom, meskipun pembelajarannya daring (online) tetapi kerjasama siswa dalam menyelesaikan tugasnya tetap terjalin dengan baik (Prudisia 2020).

Semua sarana dan prasarana yang ada pasti digunakan, seperti mengunakan LCD, WhatsApp, Google Claasroom, untuk menampilkan power point, peta konsep dan mind mapping atau memutarkan film, video, lagu, guru sejarah dalam mengajarkan materi pergerakan nasional itu melalui daring (online) karena sekolah sekarang ini menerapkan pembelajaran daring (online) maka dalam mengajarkan materi sejarah pergerakan nasional guru terlebih dahulu membuat ringkasan materinya, kemudian membuat power point materi sejarah pergerakan nasional dan peta konsepnya terutama mengajarkan materi-materi tokoh sejarah pergerakan nasional seperti organisasi Budi Utomo, Indische Partij, PNI, NU, Muhammadiyah, RA Kartini, dan sebagainya, kemudian guru memerintahkan siswa untuk membuat tugas makalah individu, membuat tugas kelompok mind mapping, serta peta konsep siswa kelas XI IPS 2 dan siswa kelas IPS 1 dari materi sejarah pergerakan nasional, kemudian hasil kerja siswa itu diupload di Google Classroom (Prudisia 2020) 
SHEs: Conference Series 3 (2) (2020) 60 - 68

Siswa yang mempelajari materi sejarah pergerakan nasional untuk memahami masa lalu mereka sendiri dan koneksi dari masa lalu. Siswa bisa lebih siap untuk memainkan peran dan rencana untuk masa depan. Siswa bisa menghormati masa lalu, dan tahu apa yang bisa mereka lakukan untuk melindungi dan mempromosikan budaya dan sejarah siswa sendiri. Siswa bisa menjadi warga negara yang baik. Siswa bangga untuk memberitahu dunia siapa mereka, dari mana mereka berasal dan apa saja yang telah mereka raih.

\section{c. Evaluasi Pembelajaran}

Evaluasi pembelajaran adalah kegiatan mengevaluasi hal-hal yang dilakukan dalam proses pembelajaran meliputi perencanaan, pelaksanaan dan proses penilaian serta dampaknya terhadap peserta didik. Evaluasi ini dilakukan dengan tujuan dapat memperbaiki kekurangan dalam pembelajaran, dan dapat dijadikan dasar untuk proses pembelajarannya selanjutnya (Lukum 2015) Model evaluasi berguna dalam membimbing pengelolaan, pengumpulan data dan analisis (Lukum 2015) Evaluasi pembelajaran merupakan alat indikator untuk menilai pencapaian tujuan-tujuan yang telah ditentukan serta menilai proses pelaksanaan mengajar secara keseluruhan. Evaluasi bukan hanya sekedar menilai suatu aktivitas secara spontan dan insidental, melainkan merupakan kegiatan untuk menilai sesuatu secara terencana, sistematik, dan terarah berdasarkan tujuan yang jelas (Hanum 2013).

Evaluasi dan hasil pembelajaran sejarah dalam upaya menanamkan nilai-nilai toleransi dan patriotisme melihat berbagai aspek penilaian. Guru sejarah di SMA Negeri 11 Yogyakarta sudah melakukannya dengan baik secara keseluruhan. Menurut (Anas 2007) mengatakan bahwa evaluasi hasil belajar dapat terlaksana dengan baik apabila dalam pelaksanaannya berpegang pada tiga prinsip yaitu prinsip keseluruhan, prinsip kesinambungan, dan prinsip obyektivitas. Berarti prinsip keseluruhan dan kesinambungan sudah dilaksanakan dengan baik oleh guru sejarah. Hal ini berdasarkan bahwa aspek yang digunakan sebagai penilaian hasil belajar berpedoman pada aspek kognitif, afektif, dan psikomotorik. Aspek penilaian dari mata pelajaran sejarah zaman pergerakan nasional berdasarkan olah dokumen format penilaian terdiri dari: 1. Aspek sikap seperti: penilaian observasi, penilaian diri, dan penilaian teman sebaya. 2. Aspek pengetahuan seperti: tes lisan atau observasi terhadap diskusi, membuat makalah individu, dan mind mapping sebagai tugas kelompok, penugasan, tanya jawab dan percakapan, praktek monolog atau dialog, post test, tertulis uraian dan pilihan ganda. 3. Aspek keterampilan seperti: penilaian unjuk kerja, penilaian proyek, penilaian portofolio, dan penilaian produk. (lampiran format penilaian mata pelajaran sejarah pergerakan nasional).

\section{d. Kesulitan-Kesulitan Yang Dihadapi Guru Sejarah Dalam Pembelajaran}

Pelaksanaan pembelajaran erat kaitannya dengan penciptaan lingkungan yang memungkinkan siswa secara aktif, pengembangan aspek pengetahuan, sikap dan keterampilan siswa, penyesuaian dengan rencana kegiatan dan pengelolaan pembelajaran. Proses pembelajaran harus beorientasi kepada lingkungan tanpa mengabaikan prinsip kepribadian, dan hasil pendidikan harus bermanfaat dan dimanfaatkan oleh masyarakat. Proses dalam menanamkan nilai-nilai toleransi dan patriotisme tidak secara otomatis dapat diterapkan oleh siswa dalam kehidupan seharihari. Dengan guru sejarah menjelaskan nilai-nilai tersebut, tidak lantas secaralangsung siswa dapat merespon penjelasan tersebut dan menanamkan reaksi positif berupa perilaku yang berkarakter. Perlu waktu untuk siswa agar bisa menanamkan nilai tersebut dalam dirinya, serta tidak menutup kemungkinan bahwa dalam penanaman nilai-nilai toleransi dan patriotisme melalui pembelajaran sejarah terdapat beberapa hambatan.

Kesulitan yang dijumpai dalam pembelajaran sejarah materi pergerakan nasional adalah hambatan waktu pembelajaran yang sedikit, sedangkan materi sejarah pergerakan nasional banyak, sehingga dalam mengajarkan materi sejarah pergerakan nasional tidak bisa dijelaskan secara lengkap, hanya diambil materi-materi yang penting- 
penting saja yang akan di ujikan dalam ulangan harian, MID, dan UAS karena siswa jika diberikan materi pelajaran terlalu banyak maka mereka bisa merasa jenuh dalam belajar, dan karena saat ini pembelajaran melalui daring (online) sehingga guru tidak bisa memantau apa saja yang dilakukan oleh siswa sebagaimana halnya ketika pembelajaran dilakukan dikelas. (Prudisia 2020) Upaya yang dilakukan oleh guru sejarah dalam mengatasi kesulitan yang muncul dalam penanaman nilai-nilai toleransi dan patriotisme adalah dengan menjadikan dirinya sebagai teladan bagi peserta didiknya, dan motivator dengan memperingati hari-hari besar nasional seperti: hari kebangkitan nasional, sumpah pemuda, 17 Agustus 1945, Kesaktian Pancasila, mengadakan agenda wajib kunjungan ke tempat-tempat bersejarah.

\section{SIMPULAN}

Persiapan pembelajaran sejarah di SMA Negeri 11 Yogyakarta telah direncanakan dengan sangat baik oleh guru sejarah. Hal ini dapat dibuktikan dengan adanya perangkat pembelajaran yang telah disusun dan disesuaikan dengan kurikulum 2013. Pelaksanaan pembelajaran, sudah direncanakan dalam perangkat pembelajaran, pertama guru mengajukan pertanyaan kepada siswa terkait materi yang dipelajari oleh siswa, kedua guru membagi siswa dalam beberapa kelompok, karena metode pembelajaran yang digunakan adalah metode diskusi, ketiga makalah individu yang tidak presentasi wajib memberikan pertanyaan kepada makalah yang tampil atau yang presentasi, dan setelah diskusi selesai guru memberikan lima pertanyaan kepada siswa yang tidak presentasi atau diberikan post test. Evaluasi dalam pembelajaran sejarah, guru sejarah telah mengunakan prinsip evaluasi keseluruhan dan kesinambungan dan sudah dilaksanakan dengan baik oleh guru sejarah. Kesulitan yang dihadapi guru sejarah adalah waktu belajar yang sedikit, dan sekarang ini pembelajaran daring (online) maka guru sulit untuk bersosialisasi dengan siswa. Upaya yang dilakukan guru sejarah, dalam mengatasi kesulitan tersebut adalah menjadikan dirinya sebagai teladan dan motivator bagi siswanya.

\section{DAFTAR PUSTAKA}

Agung, Leo \& Wahyuni, Sri. 2013. "Perencanaan Pembelajaran Sejarah. No Title." In , 10. Yogyakarta: Ombak.

Anas, Sudijono. 2007. Pengantar Evaluasi Pendidikan. Jakarta: PT. Grafindo Persada.

Bakry, Noor MS. 2010. Pendidikan Pancasila. Yogyakarta: Pustaka Pelajar.

Casram. 2016. "Sikap Toleransi Beragama Dalam Masyarakat Plural." Wawasan: Jurnal Ilmiah Agama Dan Sosial Budaya 1 (2). https://doi.org/http://dx.doi.org/10.15575/jw.v1i2.588.

Chaerulsyah, Edwin Mirza. 2014. "Persepsi Siswa Tentang Keteladanan Pahlawan Nasional Untuk Meningkatkan Semangat Kebangsaan." Indonesian Journal of History Education 3 (1).

Darmadi, Hamid. 2007. Dasar Konsep Pendidikan Moral. Bandung: ALFABETA.

Dimyati \& Mudjiono. 2013. Belajar Dan Pembelajaran. Jakarta: Rineka Cipta.

Fimansyah, Wira, and Dyah Kumalasari. 2015. "PENANAMAN NILAI-NILAI NASIONALISME MELALUI PEMBELAJARAN SEJARAH DI SMA KEBANGSAAN YOGYAKARTA." ISTORIA: Jurnal Pendidikan Dan IImu Sejarah. https://doi.org/10.21831/istoria.v11i1.5766.

Fitri, Annisa. 2017. "PERENCANAAN PEMBELAJARAN KURIKULUM 2013 PENDIDIKAN ANAK USIA DINI." Jurnal IImiah POTENSIA. https://doi.org/10.33369/jip.2.1.

Hanum, Numiek Sulistyo. 2013. "Keefetifan E-Learning Sebagai Media Pembelajaran (Studi Evaluasi Model Pembelajaran e-Learning SMK Telkom Sandhy Putra Purwokerto)." Jurnal Pendidikan Vokasi. https://doi.org/10.21831/jpv.v3i1.1584. 
Hazlitt, Henry. 2003. Dasar-Dasar Moralitas. Yogyakarta: Pustaka Pelajar.

I Ilyasin, S Amin, HT Atmaja. 2019. "Persepsi Siswa Etnis Tionghoa Terhadap Pembelajaran Sejarah Pokok Bahasan Pergerakan Nasional Di SMA Kristen Wonosobo." Indonesian Journal of History.

Lukum, Astin. 2015. "EVALUASI PROGRAM PEMBELAJARAN IPA SMP MENGGUNAKAN MODEL COUNTENANCE STAKE." Jurnal Penelitian Dan Evaluasi Pendidikan. https://doi.org/10.21831/pep.v19i1.4552.

P. Firdaus dan Ahmad. 2018. "Kesadaran Sejarah Siswa Terhadap Ketokohan Dan Keteladanan Sunan Kudus Di MA Qudsiyyah Kudus Tahun Pelajaran 2017/2018." Indonesian Journal of History Education Vol 6 No 2: 151.

Prudisia, Yuris. 2020. "Wawancara Pribadi Dengan Guru Sejarah SMA Negeri 11 Yogyakarta." Yogyakarta.

Setianto, Yudi. 2019a. "Pendidikan Karakter Melalui Keteladanan Pahlawan Nasional." Jurnal Publikasi Pendidikan Volume 9 N: 181-82.

—. 2019b. "Pendidikan Karakter Melalui Keteladanan Pahlawan Nasional." Jurnal Publikasi Pendidikan 9 (2). https://doi.org/p-ISSN 2088-2092 e-ISSN 2548-6721.

Sugiman, Ainun Muchlisatun Rati. 2017. "PENANAMAN NILAI-NILAI NASIONALISME DAN PATRIOTISME MELALUI MATERI SIKAP SEMANGAT KEBANGSAAN DAN PATRIOTISME DALAM KEHIDUPAN BERMASYARAKAT, BERBANGSA DAN BERNEGARA PADA PEMBELAJARAN PKn DI SMAN 1 PUNDONG." Academy Of Education Journal. Pendidikan Pancasila Dan Kewarganegaraan 8 (2): 175.

Wisnarni. 2017. "MENUMBUHKEMBANGKAN KARAKTER CINTA TANAH AIR MELALUI KEGIATAN EKSTRAKURIKULER BERBASIS KEBIASAAN PADA SDN NO 119/III KOTO MAJIDIN HILIR." Jurnal Tarbawi 13 (1): 51.

Yefterson, Ridho Bayu, and Abdul Salam. 2017. "Nilai-Nilai Kesejarahan Dalam Pembelajaran Sejarah Indonesia (Studi Naturalistik Inkuiri Di Sma Kota Padang)." DIAKRONIKA 17 (2).

Zais, Robert S. 1976. Curriculum: Principles and Foundations. New York: Crowell 